\title{
Psychological and Social Correlates of Students' Interest in Schooling in Obio/Akpor Local Government Area of Rivers State.
}

\author{
Love Nwamadi PhD* \\ Department of Educational Psychology, Guidance and counseling. Ignatius Ajuru University of Education, \\ Rumuorlumeni, Port-Harcourt, Rivers State, Nigeria.
}

*Corresponding Author: Love Nwamadi PhD, Department of Educational Psychology, Guidance and counseling. Ignatius Ajuru University of Education, Rumuorlumeni, Port-Harcourt, Rivers State, Nigeria.

\begin{abstract}
The study investigated psychological and social correlates of students' interest in schooling in Obio/Akpor Local Government Area of Rivers State. The design for the study was ex-post-facto research design. The population of the study was 300 students from 10 selected schools in the local government area. A questionnaire tagged "Student School Interest Scale" (SSIS) was used to collect data for the study. The reliability of the instrument was 0.65 . Four research questions as well as hypotheses were formulated for the study. The data collected were analyzed with mean and standard deviation for research questions, while the hypotheses were tested with independent t-test statistics. From the analysis, self-esteem, locus of control and parental educational level had significant relationship with students interest in schooling whereas peer group was not significantly related to students interest in schooling. Based on the findings, it was recommended that teachers and parents should try and build self-confidence in their wards/students as it could boost students' interest in learning and improve their attitude towards school.
\end{abstract}

Keywords: Psychological factors (Self-esteem, Locus of control) and Social factors (Peer group, Parental educational level).

\section{INTRODUCTION}

Schooling generally is commonly known as an education, or training giving to the student in an organized environment. It is also known as the process of acquiring knowledge and other worthwhile values from a specific confined environment. Nigeria in its $21^{\text {st }}$ century is paying serious attention to education (schooling), as a tool for sustainable development, stability, unity and progress. The National Policy on Education (2004) refers to education as an instrument per-excellence for effective national development. It further acknowledge education as an access or source for the achievement of national policy, objectives and the attainment of national goals.

Okoi (2012) asserted that such recognition to education makes it an indispensable means for effective participation not only in socio-economic development of Nigeria as a country, but also in the ongoing rapid globalization. It therefore means that, the abandonment of education or schooling and its activities will eventually affect the development of the people and impoverish the development of the affected area, hinder other achievement and the realization of the countries national goals and objective.

For students to get maximum benefit from schooling, they must have positive and responsible attitude towards schooling. This is so because, when the students' attitude is seen as positive to school, they derive satisfaction in attending to school activities and develop interest in ensuring their school obligations, and also enjoy the learning processes and become committed to their school work. But when their attitude is negative towards schooling, they absent themselves from school activities and prefer to engage in un-educative practices, against their academic responsibilities.

Schooling is a very important practice that is embraced by all and sundry, both parent and the government as a whole. Students desire to go to school especially when they remember their engagement with fellow students, teachers and other school entities during break and after the school period, which reinforces their aspirations to attend school. But recently it is observed that most students desire other anti-social activities against schooling, in which, they no longer show concern to 
school activities but prefers to indulge in irrelevant practices that does not have any positive influence on their intellectual and social development.

Most students avoid their fellow students and their teachers due to their involvement in an uneducative activities, they are no longer committed to their school work and obligations, rather, are seen in public places such as, the market places selling and buying goods during the school period, some are seen in the motor parks, garages moderating the passengers and the motorist, others are found around this mentioned places hawking water and other goods, while, some are seen in prohibited areas, beer parlors, decayed uncompleted buildings, drinking alcohol and smoking tobacco such as, cigarette and other hard drugs such as marijuana, cocaine and other easily accessed drugs, also catching other funs as they claim it is a way of reducing stress and inspiring themselves for their better understanding of their environment, Which is not the purpose for which the environment is created for.

Self-esteem reflects a person's overall subjective emotional evaluation of his or her own worth. It is a judgment of oneself as well as an attitude toward the self. Self-esteem encompasses beliefs about oneself, (for example, I am competent, I am worthy), as well as emotional states, such as triumph, despair, pride, and shame(Hewitt, 2009). According to Galbraith (2011), self-esteem is a feeling that guides individuals' behaviour. It is a driving force behind motivation. Studies have revealed that there is a close relationship between self-esteem and the interest of learners to schooling (Wiggin 1994; Anthony, 2007). Zeinvand (2006) observed that students with low self-esteem do not only feel dejected or discouraged in school, rather such students cannot solve their problems at school whenever they face it, whether it is academic or social. Maruyama (2008) also found that students who generally feel confident have a greater urge for schooling and show better performance in all areas of their studies whereas those who demonstrate less confidence show low performance.

The concept of locus of control refers to whether people attribute their successes and failures to internal or external factors as well as the extent to which people perceive themselves to be in control of the activities or events that influence their lives (William, 2013). Rotter (1966) considered locus of control as an individual's tendency to view outcome as contingent upon their own efforts (skills, abilities) or on factors outside their control. He posited that an individual's likelihood of success depends on the extent to which they see themselves as in control over or able to influence events around them. People with internal locus of control view the outcomes of their actions when they fail or succeed at something, as caused by them. They have the tendency to change strategies and persist amidst difficulty until they succeed. On the other hand, individuals with external locus of control tend to blame their outcomes on factors such as luck, fate, chance, and other people. The fact that they believe that they lack control over events in their lives means that they may not want to try other strategies or persist with the activity and consequently, they may quit trying.

Several studies have linked locus of control to students' interest in schooling. for instance, Gifford, Bricelo-Perriott and Mianzo (2006) found that college students who were identified as having internal locus of control obtained significantly higher GPAs and show high interest to schooling. Carden (2004) found that students with internal locus of control showed significantly lower academic procrastination, debilitating test anxiety, and reported higher academic achievement than those with external locus of control. Amadi (2010) and Araromi (2010) in their studies positd that both internal and external locus of control are important predictors of student's interest and academic achievement in schooling.

The importance of peer group pressure on the students interest to school, cannot be underrated in the educational sector, due to its influence exerts on students. Peer group is a collection of people, small group or clique with common interest and shares close relationship among selves. They are forces and are seen, as mini gods that exerts both negative and positive influences on the members in same or different environment. Omotere (2011) found out that peer group could either positively or negatively influence the academic performance of in-school adolescents. Lubber (2006) maintained that students who were accepted by their cliques had lower probabilities to retain a grade or to move downwards in their academic achievement.

Studies have revealed that parents' level of education is part of a larger constellation of psychological and sociological factor influencing children's school outcomes. Well-educated parents are more likely 
to make better educational choices for their children regardless of financial constraints (Onwuhaa, 2013). Likewise uneducated or undereducated parents will not be able to assist their children to gain mastery of academic content, develop interest in schooling and/or to express opinions and answer questions posed by their teachers (Muola, 2010).

Evidence presented by Lareau (1997) indicated that less-educated parents rely more on schools for children's educational development than highly educated parents, who see teachers as partners and are more construed to provide children with the needed educational assistance at home. Consequently, it can be argued that most educated parents demand a better education for their children. Educated parents are not only able to supervise their children's school work, they are also able to encourage them towards higher performances and prompt attendance to homework and participation in other school-oriented activities (Lareau, 1997).

\section{Aim AND OBJeCtives Of THE STUDY}

The aim of the study is to examine psychological and social correlates of students' interest in schooling in Obio/Akpor Local Government Area of Rivers State. Specifically this study intends to;

- Investigate the relationship between self-esteem and students' interest in schooling in Obio/Akpor Local Government Area of Rivers State.

- Examine the relationship between locus of control and students' interest in schooling in Obio/Akpor Local Government Area of Rivers State.

- Determine the relationship between peer group students' interest in schooling in Obio/Akpor Local Government Area of Rivers State.

- Investigate the influence between parental educational status and interest towards schooling in Obio/Akpor Local Government Area of Rivers State.

\section{RESEARCH QUESTIONS}

- To what extent does self-esteem correlates with students' interest in schooling in Obio/Akpor Local Government Area?

- To what extent does locus of control correlates with students' interest in schooling in Obio/Akpor Local Government Area?

- To what extent does peer group correlates with students' interest in schooling in Obio/Akpor Local Government Area?

- To what extent does parental educational status correlates with students' interest in schooling in Obio/Akpor Local Government Area?

\section{RESEARCH HYPOTHESES}

- Self-esteem does not significantly relate with students' interest in schooling in Obio/Akpor Local Government Area.

- Locus of control does not significantly relate with students' interest in schooling in Obio/Akpor Local Government Area.

- Peer group does not significantly relate with students' interest in schooling in Obio/Akpor Local Government Area.

- Parental educational level does not significantly relate with students' interest in schooling in Obio/Akpor Local Government Area.

\section{ReSEARCh Methods AND Procedure}

A total sample of 300 students randomly selected using the simple sampling technique (balloting) was used for this study. An instrument tagged "Student School Interest Scale" (SSIS) was used to collect data for the study. The reliability was established through the test-re-test method. The obtained reliability index for (SSIS) was 0.69 
Psychological and Social Correlates of Students' Interest in Schooling in Obio/Akpor Local Government Area of Rivers State.

\section{Data Analysis}

Data collected was analyzed using mean, standard deviation independent t-test statistics. The results of the research questions and their corresponding null hypotheses are presented together in the same table.

\subsection{Research Question 1}

To what extent does self-esteem correlates with students' interest in schooling in Obio/Akpor Local Government Area?

\section{Hypothesis 1}

Self-esteem does not significantly relate with students' interest in schooling in Obio/Akpor Local Government Area.

Table1. Showing relationship between self-esteem and students' interest to schooling in Obio/Akpor Local Government Area

\begin{tabular}{|l|l|l|l|l|l|l|l|}
\hline Self-esteem & N & $\bar{X}$ & SD & df & t-cal & t-crit & Result \\
\hline Low & 98 & 84.97 & 14.13 & 198 & 13.67 & 1.96 & S \\
\hline High & 102 & 56.27 & 15.49 & & & & \\
\hline
\end{tabular}

The result of the data analyzed showed that low self-esteem had mean score of 84.97 and SD $=14.13$ while, high self-esteem had mean score of 56.27and SD $=15.49$. Since the t-calculated of 13.67 is higher than t-critical of 1.96, it means that the null hypothesis was rejected and alternate accepted. Therefore, there exist a significant relationship between self-esteem and students' interest to schooling in Obio/Akpor Local Government Area.

\subsection{Research Question 2}

To what extent does locus of control correlates with students' interest in schooling in Obio/Akpor Local Government Area?

\section{Hypothesis 2}

Locus of control does not significantly relate with students' interest in schooling in Obio/Akpor Local Government Area

Table2. Showing the relationship between Locus of control and students' interest to schooling in Obio/Akpor Local Government Area

\begin{tabular}{|l|l|l|l|l|l|l|l|}
\hline Locus of control & $\mathbf{N}$ & $\bar{X}$ & SD & df & t-cal & t-crit & Result \\
\hline Internal & 106 & 84.82 & 16.17 & 198 & 9.039 & 1.96 & $\mathrm{~S}$ \\
\hline External & 102 & 50.52 & 18.71 & & & & \\
\hline
\end{tabular}

The result of the data analyzed showed that internal locus of control had mean score of 84.82 and SD $=16.17$ while, external locus of control had mean score of 50.52 and SD $=18.71$. Since the $t-$ calculated of 9.039 is higher than t-critical $=1.96$, it implies that the null hypothesis was rejected and alternate accepted. Hence there exist a significant relationship between locus of control and students' interest to schooling in Obio/Akpor Local Government Area.

\subsection{Research Question 3}

To what extent does peer group correlates with students' interest in schooling in Obio/Akpor Local Government Area?

\section{Hypothesis 3}

Peer group pressure does not significantly relate with students' interest in schooling in Obio/Akpor Local Government Area.

Table3. showing the relationship between Peer group pressure and students' interest to schooling in Obio/Akpor Local Government Area

\begin{tabular}{|l|l|l|l|l|l|l|l|}
\hline Peer group pressure & N & $\bar{X}$ & SD & df & t-cal & t-crit & Result \\
\hline Low & 120 & 70.83 & 20.65 & 198 & .615 & 1.96 & NS \\
\hline High & 80 & 68.69 & 20.73 & & & & \\
\hline
\end{tabular}


The result of the data analyzed showed that low peer group pressure had mean score of 70.83 and SD $=20.65$ while, high peer group pressure had mean score of 68.69 and SD $=20.73$ The data analyzed revealed that the two groups do not differ significantly in their mean scores. The result also showed that the t-calculated of .615 is less than t-critical of 1.96 , indicating that there is no significant relationship between peer group pressure and students' interest to schooling in Obio/Akpor Local Government Area. Hence the null hypothesis is retained (see table 3 above).

\subsection{Research Question 4}

To what extent does parental educational status correlates with students' interest in schooling in Obio/Akpor Local Government Area?

\section{Hypothesis 4}

Parental educational level does not significantly relate with students' interest in schooling in Obio/Akpor Local Government Area.

Table4. Showing the relationship between Parental educational level and students' interest to schooling in Obio/Akpor Local Government Area

\begin{tabular}{|l|l|l|l|l|l|l|l|}
\hline Parental educational level & N & $\bar{X}$ & SD & df & t-cal & t-crit & Result \\
\hline Low & 96 & 81.14 & 16.87 & 198 & 8.215 & 1.96 & S \\
\hline High & 104 & 60.36 & 18.74 & & & & \\
\hline
\end{tabular}

The result of the data analyzed showed that low parental educational level had mean score of 81.14 and $\mathrm{SD}=16.87$ while, high parental educational level had mean score of 60.36 and SD $=18.74$. Since the t-calculated of 8.215 is higher than $\mathrm{t}$-critical $=1.96$, it implies that the null hypothesis was rejected and alternate accepted. Hence there exist a significant relationship between Parental educational level and students' interest to schooling in Obio/Akpor Local Government Area. (see table 4 above)

\section{RESEARCH FINDINGS AND DISCUSSION}

\subsection{Self-esteem and Students' Interest to Schooling}

The result and findings of this study showed that self-esteem (high/low) had a significant relationship with students' interest to schooling in Obio/Akpor Local Government Area. However, low selfesteem seem to relate more with students' interest to schooling than high self-esteem. The findings of this study is in agreement with an earlier study by Zeinvand (2006) observed that students with low self-esteem not only feel dejected or discouraged in school, rather such students cannot solve their problems at school whenever they face it, whether it is academic or social.

\subsection{Locus of Control and Students' Interest to Schooling}

The result of this study showed that there exist a relationship between locus of control and students' interest to schooling in Obio/Akpor Local Government Area. Further analysis of the result revealed that internal locus of control relates more with students' interest in schooling than external locus of control. To this end it can be said that individuals with internal locus of control seem too have positive regard and interest in schooling than their counterparts with external locus of control. This reason could be because people with internal locus of control tend to accept and attribute both their success and failures as caused by them, and strive to work better at it next time. The present study is in agreement with an earlier study by Carden (2004) who found that students with internal locus of control showed significantly lower academic procrastination, debilitating test anxiety, and reported higher academic achievement than those with external locus of control.

\subsection{Peer Group Pressure and Students' Interest to Schooling}

The result revealed that peer group pressure those not significantly relate with students' interest to schooling in Obio/Akpor local Government Area. The findings of this study, however does agree with some past research findings. For example, Lubber (2006) maintained that the students who were accepted by their cliques had lower probabilities to retain a grade or to move downwards in their academic achievement. And Omotere (2011) who found out that peer group could either positively or negatively influence the academic performance of in-school adolescents. 


\subsection{Parental Educational Level and Students' Interest to Schooling}

The result of the study showed that parental educational level had a significant relationship between parental educational level and students' interest to schooling in Obio/Akpor local Government Area. The present study agrees with an earlier study byLareau (1997) whose findings showed that students whose parents had higher educational levels performed higher on standardized tests than students having parents with lower educational levels.

\section{CONCLUSION AND RECOMMENDATIONS}

Schooling is a very important practice that is embraced by all and sundry, both parent and the government. Students desire to go to school especially when they remember their engagement with fellow students, teachers and other school entities during break and after the school period, which reinforces their aspirations to attend school.But in recent times it is observed that most students desire other anti-social activities against schooling, in which, they no longer show concern to school activities but prefers to indulge in irrelevant practices that does not have any positive influence on their intellectual and social development. This study has looked some factors relating to students' interest in schooling especially in Obio/Akpor local Government Area. Based on the findings of this study, the researcher therefore recommends that, teachers and parents should try and build selfconfidence in their wards/students as it could boost students' interest in learning and improve their attitude towards school. Teachers/facilitators should also explain all subject matter in a way that each student can comprehend in order to arouse their interest in the subject.

\section{REFERENCES}

[1] Anthony, D. B., Holmes, J. G., \& Wood, J. V. (2007). Social acceptance and self-esteem: Tuning the sociometer to interpersonal value. Journal of Personality and Social Psychology, 92(6), 1024-1039.

[2] Amadi (2010) Affective determinant of ESL Success, Unpublished M.ed.Project, Department of Teacher Education University of Ibadan,Ibadan.

[3] Araromi, M. (2010). Motivation, Verbal Ability, Attitude, Gender and Locus of Control as Predictors of Academic Achievement in French, A seminar Paper presented in the department of Teacher education.university of Ibadan.

[4] Carden, R., C. Bryant, and R. Moss. 2004. "Locus of Control, Test Anxiety, Academic Procrastination, and Achievement among College Students," Psychological Reports, 95, 581-582.

[5] Galbraith, Alison, and Alexander, J. (2011) Literacy, self-esteem and locus of control. Support for Learning: pp. 20-41.

[6] Gifford, D. D., Bricelo, A., Perriott, J., \&Mianzo, F (2006). Locus of control: academic achievementand retention in a sample of university first-year students. J. Coll. Admission.191:18-25

[7] Lareau S. F. (1997), "Social class and Academic achievement; A third world Reinterpretation" comparative Education Review 25 (3) 419-430 academic achievement. Journal of continuous in Nigeria.

[8] Lubbers, M. J. (2006). The social fabric of the classroom. Peer relations in secondary education. Doctoral thesis. University of Groningen, The Netherlands

[9] Maruyama, G. M., Rubin, R. A., \& Kingsbury, G. G. (1981). Self-esteem and educational achievement: Independent constructs with a common cause? Journal of Personality and Social Psychology, 40(5), pp. 623-655

[10] Muola, J.M .(2010),. A Study of the Relationship between academic achievement motivation and home environment among standard eight pupils. In Educational Research and Reviews. Egerton University of Kenya.

[11] Okoi, J. D. (2012). Philosophy of Education: The Basics. Owerri: Corporate Impressions.

[12] Omotere, T. (2011). The influence of peer group on adolescents' academic performance: A case study of some selected schools in Ogun State. Ogun: Ego Booster Publishers.

[13] Onwuhaa, J. (2013), The study of the Influence of family size and socio-economic status of parents on Academic performance of primary school pupils in Enugu East local Government Area. An unpublished M.Ed Thesis Ahmadu Bello University.

[14] Rotter, J. B(1966). Generalized expectancies for internal versus external control of reinforcement. Psychological Monographs, 80,1-28

[15] Wiggins, J.D., Schatz, E.L., \& West, R.W. (1994). The relationship of self-esteem to grades, achievement scores, and other factors critical to school success. The School Counselor, 4, pp.130-149 
[16] Williams, J. D. (2013). Student engagement at school: A sense of belonging and participation. Organization for Economic Cooperation and Development.

[17] Zeinvand, A. (2006)Relationships between self esteem, social support and student's educational progression in a high school in Dareh Shar city in Iran. University of TabiatMoallem, Theran, Iran

\section{AUTHOR'S BIOGRAPHY}

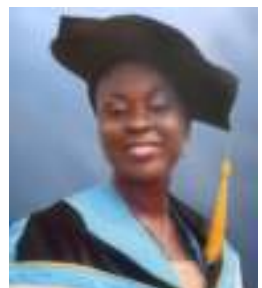

Dr. (Mrs) Love Nwamadi, is a native of Umuoko in Omuma Local Government Area of Rivers State.She holds a bachelor's degree in Educational psychology, Guidance and counseling and a Master's degree in Educational psychology from the University of Port-Harcourt, she obtained a Ph.D degree six years ago from Delta State University, Abraka.

She is currently a senior lecturer in the department of Educational Psychology, Guidance and counseling, Ignatius Ajuru University of Education, Port-Harcourt, Rivers State.

She has made contributions in both international and national Journals of great repute.

Her area of interest is on personality and social psychology.

Citation: Love Nwamadi PhD "Psychological and Social Correlates of Students' Interest in Schooling in Obio/Akpor Local Government Area of Rivers State." International Journal of Humanities Social Sciences and Education (IJHSSE), vol 5, no. 1, 2018, pp. 63-69. doi: http://dx.doi.org/10.20431/2349-0381.0501010.

Copyright: $\odot 2018$ Authors. This is an open-access article distributed under the terms of the Creative Commons Attribution License, which permits unrestricted use, distribution, and reproduction in any medium, provided the original author and source are credited. 